\title{
ANALISIS BAURAN PEMASARAN TERHADAP MINAT BELI SAYUR HIDROPONIK DI POKDARWIS ( KELOMPOK SADAR WISATA) OLEAN
}

\author{
Nurma Novia Oky Chandra1), Yasmini Suryaningsih ${ }^{2 *}$ \\ Fakultas Pertanian, Universitas Abdurachman Saleh Situbondo \\ *Email Korespondensi : jasminumsambac13@gmail.com
}

\begin{abstract}
Abstrak
Tujuan penelitian ini untuk mengetahui pengaruh produk, harga, promosi, dan lokasi terhadap minat beli sayur hidroponik di POKDARWIS Olean serta untuk mengetahui variabel yang paling dominan terhadap minat beli sayur hidroponik di POKDARWIS Olean. Daerah penelitian ditentukan menggunakan metode purposive dengan pertimbangan karena POKDARWIS Olean adalah salah satu objek wisata edukasi hidroponik di Kabuaten Situbondo serta memiliki lingkup pasar yang relatif luas. Metode penelitian yang digunakan adalah metode deskriptif dan kuantitatif, sedangkan data yang di peroleh dari lapangan akan di analisa dengan menggunakan analisis regresi linier berganda, uji $t$, dan uji F. Hasil penelitian menunjukkan bahwa sebagian aspek bauran pemasaran yang terdiri dari produk dan harga memiliki pengaruh yang signifikan terhadap minat beli sedangkan aspek bauran pemasaran lainnya yang terdiri dari promosi dan lokasi tidak memiliki pengaruh signifikan terhadap minat beli. Selain itu, dari penelitian ini di peroleh hasil yang menunjukkan bahwa variabel produk merupakan variabel yang paling dominan terhadap minat beli sayur hidroponik di POKDARWIS Olean dengan nilai koefisien regresi sebesar 0,480 .
\end{abstract}

Kata kunci: Hidroponik, Bauran Pemasaran, Minat Beli

\begin{abstract}
The purpose of this study was to determine the effect of product, price, promotion, and location on hydroponic vegetable buying interest in POKDARWIS Olean as well as to find out the most dominant variable towards hydroponic vegetable buying interest in POKDARWIS Olean. The research area was determined using a purposive method with consideration because POKDARWIS Olean is one of the hydroponic education attractions in Situbondo District and has a relatively wide market scope. The research method used is descriptive and quantitative methods, while the data obtained from the field will be analyzed using multiple linear regression analysis, $t$ test, and $F$ test. The results of the study show that some aspects of the marketing mix consisting of products and prices have an influence significant effect on buying interest while other marketing mix aspects consisting of promotions and locations do not have a significant influence on buying interest. In addition, the results obtained from this study indicate that the product variable is the most dominant variable in hydroponic vegetable buying interest in POKDARWIS Olean with a regression coefficient of 0.480.
\end{abstract}

Key Words: Hydroponics, Marketing Mix, Buying Interest

\section{PENDAHULUAN}

Hortikultura adalah istilah yang sering digunakan pada jenis tanaman yang dibudidayakan. Sayuran merupakan bagian kecil produk hortiluktura yang sering di jumpai di pasaran. Seiring dengan pertambahan jumlah penduduk dan peningkatan kesadaran masyarakat akan pentingnya pola hidup sehat, permintaan komoditas ini diperkirakan akan terus meningkat dari tahun ke tahun. Oleh karena itu perlu dilakukan upaya peningkatan volume produksi untuk memenuhi kebutuhan tersebut. Akan tetapi 
terdapat permasalahan di dalam meningkatkan jumlah volume yang di sebabkan oleh semakin sempitnya lahan pertanian. Hidroponik muncul sebagai alternatif pertanian pada lahan terbatas. Sistem bercocok tanam hidroponik adalah bercocok tanam tanpa menggunakan media tanah, bisa menggunakan air, kerikil dan sebagainya. Sistem ini memungkinkan budidaya sayuran di daerah yang kurang subur atau daerah sempit yang padat penduduknya, termasuk di perkotaan. Namun permalasahan lain timbul dari kalangan masyarakat yang memiliki anggapan bahwa produk hidroponik itu mahal serta masih rendahnya pengetahuan mengenai sistem hidroponik. Oleh karna itu perlu adanya upaya yang di lakukan dari para produsen sayur hidroponik untuk memperkenalkan produknya guna menarik minat beli konsumen. Penerapan aspek bauran pemasaran yang merupakan bagian dari kegiatan pemasaran bisa di jadikan suatu solusi dalam menarik minat beli konsumen.

Menurut Kotler dan Amstrong (2012) pemasaran adalah proses dimana perusahaan menciptakan nilai bagi pelanggan dan membangun hubungan pelanggan yang kuat untuk menangkap nilai dari pelanggan sebagai imbalannya. Berbicara pemasaran terdapat beberapa hal penting di dalamnya salah satunya adalah konsep bauran pemasaran. Menurut Kotler (2010) bauran pemasran adalah sekumpulan alat pemasaran yang dapat digunakan oleh perusahaan untuk mencapai tujuan pemasaran dalam pasar sasaran. Bauran pemasaran juga menentukan keberhasilan perusahaan dalam mengejar profit. Menurut Kotler dan Keller (2006), alat bauran pemasaran terdiri dari produk, harga, promosi, dan lokasi.

Menurut Kotler (2005), produk adalah apapun yang dapat ditawarkan untuk pasar yang dapat memenuhi keinginan atau kebutuhan tertentu. Dan harga adalah jumlah dari nilai yang ditukar konsumen atas manfaat-manfaat karena memiliki atau menggunakan produk barang/jasa (Kotler dan Amstrong,2001). Serta definisi promosi adalah aktifitas pemasaran yang berusaha menyebarkan informasi, mempengaruhi/ membujuk, dan mengingatkan pasar sasaran atas perusahaan dan produknya agar bersedia menerima, membeli dan loyal pada produk yang ditawarkan perusahaan yang bersangkutan (Tjiptono,2008). Sedangkan lokasi merupakan tempat melayani konsumen, dapat pula diartikan sebagai tempat untuk memajangkan barang-barang daganganya (Kasmir,2009).

Berdasarkan uraian singkat diatas, maka objek yang dipilih dalam penelitian ini adalah pada POKDARWIS Olean Kabupaten Situbondo. Pemilihan tempat penelitian ini dikarenakan POKDARWIS Olean merupakan salah satu tempat wisata edukasi berkebun hidroponik yang ada di situbondo, serta memiliki jaringan pasar yang cukup luas. POKDARWIS Olean ini merupakan suatu kelompok masayrakat desa Olean yang memiliki kesadaran akan peluang pasar sayuran yang relatif tinggi di kabupaten Situbondo sehingga dapat membantu pendapatan keluarga. Untuk mencermati peluang pasar tersebut, POKDARWIS Olean kabupaten Situbondo memerlukan adanya analisis bauran pemasaran yang tepat sehingga berimbas pada minat beli konsumen. Dimana penerapan bauran pemasaran yang baik ini berguna untuk meningkatkan minat beli dari konsumen/pelanggan atas produk sayur hidroponik yang ditawarkan.

Berdasarkan uraian tersebut, permasalahan yang dirumuskan dalam penelitian ini sebagai berikut: 1) Apakah variabel produk(Product) berpengaruh terhadap minat beli sayuran hidroponik di POKDARWIS Olean? 2) Apakah variabel harga(Price) berpengaruh terhadap minat beli sayuran hidroponik di POKDARWIS Olean? 3) Apakah variabel promosi(Promotion) berpengaruh terhadap minat beli sayuran hidroponik di POKDARWIS Olean? 4) Apakah variabel lokasi (Place) berpengaruh terhadap minat beli sayuran hidroponik di POKDARWIS Olean? 5) Variable manakah dari konsep bauran pemasaran yang mempunyai pengaruh paling dominan terhadap minat beli sayuran hidroponik di POKDARWIS Olean? 


\section{METODE PENELITIAN}

Penelitian ini menggunakan metode desain penelitian deskriptif yang diolah dengan menggunakan pendekatan kuantitatif. Penelian ini dilakukan di POKDARWIS (Kelompok Sadar Wisata) olean. Pemilihn lokasi dilakukan secara sengaja (purposive) dengan pertimbangan POKDARWIS Olean merupakan salah satu tempat wisata edukasi berkebun hidroponok yang ada di situbondo,serta memiliki jaringan pasar yang cukup luas. Teknik pengambilan sampel pada penelitian ini adalah Insidental Sampling atau Aksidental. Teknik ini dilakukan dengan cara memilih sampel yang dijumpai secara kebetulan.

\section{Metode Analisis Data}

\section{Analisis regresi linier berganda}

Analisis ini digunakan untuk mengetahui seberapa besar pengaruh variabel bebas yaitu Product / Produk (X1), Price / Harga (X2), Promotion / Promosi (X3) dan Place / Lokasi (X4) terhadap variabel terikat yaitu Minat beli (Y) sayur hidroponik di POKDARWIS Olean. Menurut Sugiyono (2010) untuk mengetahui pengaruh variabel bebas terhadap variabel terikat digunakan rumus analisis regresi linier berganda sebagai berikut:

$y=a+b_{1} x_{1}+b_{2} x_{2}+b_{3} x_{3}+b_{4} x_{4}+e$

Keterangan :

$\mathrm{Y}=$ minat beli konsumen

$\mathrm{a}=$ konstanta dari keputusan regresi

$\mathrm{b}_{1}=$ koefisien regresi dari variabel X1 (produk/ product)

$\mathrm{b}_{2}=$ koefisien regresi dari variabel X2 (harga/ price)

$\mathrm{b}_{3}=$ koefisien regresi dari variabel X3 (promosi/ promotion)

$\mathrm{b}_{4}=$ koefisian regresi dari variabel X4 (lokasi/ place)

$\mathrm{x}_{1}=\operatorname{produk}($ product $)$

$\mathrm{x}_{2}=$ harga (price)

$\mathrm{x}_{3}=$ promosi (promotion)

$\mathrm{x}_{4}=$ lokasi (place)

$\mathrm{e}=$ variabel pengganggu

\section{Uji t}

Uji t dilakukan dengan tujuan untuk menguji pengaruh variabel bebas (produk, harga, promosi, lokasi) secara individu terhadap variabel terikat (minat beli). Menurut Sugiyono (2004) formulasi perhitungan uji t adalah sebagai berikut:

$t=\frac{r \sqrt{n-2}}{\sqrt{1-r^{2}}}$

Keterangan :

$\mathrm{t}=$ Nilai hitung

$r=$ Koefisien korelasi

$\mathrm{n}=$ Banyaknya observasi

\section{Uji F}

Uji F dilakukan dengan tujuan untuk menguji pengaruh variabel bebas (produk, harga, promosi, lokasi) secara simultan terhadap variabel terikat (minat beli). Pengujian statistik uji F dengan formulasi sebagai berikut (Gujarati, 2006):

uji $F=\frac{R^{2} / k}{\left(1-R^{2}\right) /(n-k-1)}$ 
Keterangan :

$\mathrm{F}=$ Diperoleh dari tabel distribusi

$\mathrm{k}=$ Jumlah variabel bebas

$\mathrm{R}^{2}=$ Koefisien determinasi ganda

$\mathrm{n}=$ Jumlah sampel

\section{HASIL DAN PEMBAHASAN}

\section{Analisis regresi linier berganda}

Tabel 1. Hasil Analisis Regresi Linier Berganda

\begin{tabular}{llll}
\hline Model & $\mathrm{B}$ & $\mathrm{T}$ & Sig \\
\hline (constanta) & $-2,682$ & 0,000 & 1,000 \\
\hline $\mathrm{X} 1$ & 0,480 & 3,522 & 0,002 \\
\hline $\mathrm{X} 2$ & 0,265 & 2,257 & 0,033 \\
\hline $\mathrm{X} 3$ & 0,142 & 1,214 & 0,236 \\
\hline $\mathrm{X} 4$ & 0,239 & 1,556 & 0,132 \\
\hline
\end{tabular}

Berdasarkan tabel diatas dapat diperoleh persamaan regresi linier berganda sebagai berikut :

$Y=-2,682+0,480 X_{1}+0,265 X_{2}+0,142 X_{3}+0,239 X_{4}$

Dari persamaan regresi tersebut dapat diinterprestasikan sebagai berikut :

a. Nilai konstanta regresi sebesar $-2,682$, yang menunjukkan besarnya nilai minat beli konsumen sayur hidroponik di PODARWIS Olen sebesar -2,682, jika variabel lain (variabel independen) sama dengan nol atau konstan.

b. $\mathrm{X}_{1}$ (produk) nilai koefisien regresinya sebesar 0,480 , yang berarti setiap peningkatan variabel produk sebesar $1 \%$, maka minat beli konsumen akan meningkat sebesar 0,480 dengan asumsi variabel independen lain konstan.

c. $\mathrm{X}_{2}$ (harga) nilai koefisien regresinya sebesar 0,265 , yang artinya setiap peningkatan variabel harga sebesar 1\%, maka minat beli konsumen akan meningkat sebesar 0,265 dengan asumsi variabel independen lain konstan.

d. $X_{3}$ (promosi) nilai koefisien regresinya sebesar 0,142, yang berarti setiap peningkatan kegiatan variabel promosi sebesar $1 \%$, maka minat beli konsumen akan meningkat sebesar 0,142 dengan asumsi variabel independen lain konstan.

e. $\mathrm{X}_{4}$ (lokasi) nilai koefisien regresinya sebesar 0,239 , yang artinya setiap peningkatan jarak lokasi semakin dekat sebesar 1\% dari jarak awal, maka akan meningkat minat beli konsumen sebesar 0,239 dengan asumsi variabel independen lain konstan.

Dari hasil persamaan regresi linier berganda di atas terlihat variabel independen produk mempunyai pengaruh lebih tinggi atau dominan dibandingkan variabel independen lainnya yaitu variabel harga, variabel promosi dan variabel lokasi terhadap variabel dependen minat beli sayur hidroponik di POKDARWIS Olean, yang didasarkan pada nilai koefisien regresi produk sebesar 0,480 . 


\section{Uji t}

Tabel 2. Hasil Ringkasan uji t

\begin{tabular}{llllll}
\hline V ariabel & $t_{\text {hitung }}$ & $t_{\text {tabel }}$ & Nilai sig. Tabel & Batas nilai sig & Keterangan \\
\hline X1 & 3,522 & 2,059 & 0,002 & 0,05 & Ada Pengaruh Signifikan \\
\hline X2 & 2,257 & 2,059 & 0,033 & 0,05 & Ada Pengaruh Signifikan \\
\hline X3 & 1,214 & 2,059 & 0,236 & 0,05 & $\begin{array}{l}\text { Tidak Ada Pengaruh } \\
\text { Signifikan }\end{array}$ \\
\hline X4 & 1,556 & 2,059 & 0,132 & 0,05 & $\begin{array}{l}\text { Tidak Ada Pengaruh } \\
\text { Signifikan }\end{array}$ \\
\hline
\end{tabular}

Dari tabel 2 di atas hasil pengujian uji t maka dapat di simpulkan sebagian variabel independen yang terdiri dari produk dan harga memiliki pengaruh yang signifikan terhadap minat beli sedang variabel independen yang lainnya yang terdiri dari promosi dan lokasi tidak memiliki ada pengaruh signifikan terhadap minat beli. Pengambilan keputusan ini di dasari dengan membandingkan nilai probalititas signifikan tabel dengan batas nilai probalititas signifikan. Apabila nilai probalititas signifikan lebih kecil dari batas nilai probalitas signifikan maka artinya terdapat pengaruh signifikan dari variabel independen terhadap variabel dependen. Dan begitu pula sebaliknya apabila nilai probalititas signifikan lebih besar dari batas nilai probalitas signifikan maka artinya tidak ada pengaruh signifikan dari variabel independen terhadap variabel dependen.

\section{Uji F}

Tabel 3. Hasil Ringkasan uji F

\begin{tabular}{llll}
\hline$F_{\text {hitung }}$ & $F_{\text {tabel }}$ & Nilai Sig & Batas Niai Sig \\
\hline 17,130 & 2,76 & 0,000 & 0,05 \\
\hline
\end{tabular}

Dari tabel 3 uji F di atas dapat dilihat nilai signifikan 0,000<0,05 artinya secara simultan atau bersama-sama variabel independen berpengaruh terhadap variabel dependen. Dengan demikian dapat disimpulkan bahwa variabel independen yang terdiri dari produk, harga, promosi, dan lokasi dalam penelitian ini secara bersama-sama berpengaruh terhadap variabel dependen yaitu minat beli.

\section{KESIMPULAN}

Berdasarkan hasil dan pembahasan penelitian ini dapat disimpulkan sebagai berikut:

1. Produk memiliki pengaruh terhadap minat beli sayuran hidroponik di POKDARWIS olean.

2. Harga memiliki pengaruh terhadap minat beli sayuran hidroponik di POKDARWIS olean.

3. Promosi tidak memiliki pengaruh terhadap minat beli sayuran hidroponik di POKDARWIS olean.

4. Lokasi tidak memiliki pengaruh terhadap minat beli sayuran hidroponik di POKDARWIS olean.

5. Produk adalah variabel yang memiliki pengaruh paling tinggi atau dominan terhadap minat beli dengan nilai besaran pengaruh koefisien sebesar 0,480 bertanda positif sedangkan variabel lainnya memiliki nilai koefisien yang lebih rendah. 


\section{REFERENSI}

Gujarati, Damodar N. 2006. Ekonometrika Dasar. Jakarta : Penerbit Erlangga.

Kasmir. 2009. Analisis Laporan Keuangan. Jakarta. PT. Raja Grafindo Persada.

Kotler, Philip. 2005. Manajemen Pemasaran. Jilid 1 dan 2. Jakarta : PT Indeks Kelompok Gramedia.

Kotler, Philip. 2010. Manajemen Pemasaran. Edisi Milenium. Prenhallindo. Jakarta.

Kotler, Philip dan Gary Armstrong. 2001. Prinsip-Prinsip Pemasaran. Jilid 1. Erlangga, Jakarta.

Kotler, Philip dan Gary Amstrong. 2012. Prinsip-Prinsip Pemasaran. Edisi ke 13. Jilid 1. Erlangga, Jakarta.

Philip Kotler dan Kevin L. Keller. 2006. Manajemen Pemasaran edisi ke 12 Jilid ke 1. New Jersey, Indeks.

Sugiyono. 2010. Metode Penelitian Pendidikan Pendekatan Kuantitatif, kualitatif, dan R\&D. Alfabeta. Bandung.

Sugiyono. 2004. Metode Penelitian Bisnis: Penerbit CV. Alfabeta: Bandung.

Tjiptono, Fandy. 2008. Strategi Pemasaran, Edisi III. Andi. Yogyakarta 